\title{
Impact of E-Procurement Adoption on Company Performance: Evidence from Indonesian Manufacturing Industry
}

\author{
Ilyas Masudin*(D), Ganis Dwi Aprilia, Adhi Nugraha and Dian Palupi Restuputri \\ Department of Industrial Engineering, University of Muhammadiyah Malang, Malang 65144, Indonesia; \\ ganisaprilia03@gmail.com (G.D.A.); adhinugraha@umm.ac.id (A.N.); restuputri@umm.ac.id (D.P.R.) \\ * Correspondence: masudin@umm.ac.id; Tel.: +62-341464318
}

Citation: Masudin, I.; Aprilia, G.D.; Nugraha, A.; Restuputri, D.P. Impact of E-Procurement Adoption on Company Performance: Evidence from Indonesian Manufacturing Industry. Logistics 2021, 5, 16. https://doi.org/10.3390/ logistics5010016

Received: 27 January 2021

Accepted: 9 March 2021

Published: 15 March 2021

Publisher's Note: MDPI stays neutral with regard to jurisdictional claims in published maps and institutional affiliations.

Copyright: (c) 2021 by the authors. Licensee MDPI, Basel, Switzerland. This article is an open access article distributed under the terms and conditions of the Creative Commons Attribution (CC BY) license (https:// creativecommons.org/licenses/by/ $4.0 /)$.

\begin{abstract}
This study was conducted to determine the performance impact of e-procurement adoption in Indonesian manufacturing companies. This study consists of four variables: top management support, information quality, implementation of e-procurement, and company performance. Pilot testing questionnaires were used to test whether the respondents understood the questions given by the researcher. After conducting the pilot test, the final questionnaire was distributed to respondents. The pilot test results and the final questionnaire were analyzed using Statistical Package for Social Science (SPSS) version 21 and SmartPLS v3.0 software to determine the relationship between variables. The results of this study support the acceptance of three hypotheses. The results indicate that top management support has a significant effect on e-procurement implementation. Other results show that information quality has a significant effect on e-procurement implementation, while eprocurement implementation has a significant effect on company performance. From the findings of this article, recommendations from a management perspective are discussed to increase management awareness in adopting electronic procurement.
\end{abstract}

Keywords: e-procurement; performance; information quality; management support

\section{Introduction}

Procurement is an activity or process of obtaining company goods and services. The goal is to obtain the company's goods / services in carrying out its operational processes, including planning, purchasing, shipping, inspection, receiving, and storing activities. There are two processes in goods procurement activities, namely conventional and e-procurement. E-procurement is electronic procurement whose implementation process refers to an integrated communication system (web-based) to perform procurement functions, including ordering, purchasing, negotiating, and searching for raw materials in the procurement process [1]. E-procurement can make the implementation of procurement transparent, efficient, and fair. There are two benefits/advantages of applying e-procurement, according to Teo, Lin, \& Lai [2]: direct benefits can increase efficiency and effectiveness in the operation process, data accuracy, and useful application process; while indirect benefits can improve customer services. E-procurement also makes procurement more competitive and improves relationships with business partners.

In its application, several factors support the success of e-procurement. According to Gunasekaran and Ngai [3], the critical factors for successfully implementing e-procurement are management commitment to financial and technological support. Croom and BrandonJones [4] found that potential issues for improving supply chain performance by adopting e-procurement are organizational relationship and information technology infrastructure issues. The implementation of e-procurement in government organizations indicated that internal managerial supports and stakeholder involvement along the supply chain play a significant role [5]. Roehrich et al. [6] believe that managers should encourage technological experimentation with innovative ways to manage and join organizational activities. This 
would help management innovation development processes for obtaining improvements in the organization's performance.

Innovation is defined as the process whereby information technology moves into usage form [7]. IT innovation within an organization is one factor in successful technology adoption for newly industrializing and developing countries. Innovative information technology is more than allowing companies to improve overall performance and facilitate relationships and transactions between companies. Innovative IT effectively solves specific problems regarding asset and product descriptions [8]. E-procurement results in utilization of innovative developments in information technology to procure goods/services. The effectiveness of e-procurement depends on the platforms applied in the business. A study by Tai et al. [9] found that e-procurement is based on web-based impact on supply chain performance. Priya et al. [10] used online analytical processing (OLAP) for competitive e-procurement. Moreover, the decision to choose e-procurement technology platforms has been made using different approaches such as the analytic hierarchy process (AHP) [11], analytic network process (ANP) [12], and hybrid fuzzy TOPSIS [13]. This indicates that the quality of information technology used in adopting e-procurement plays a significant role in its implementation.

The application of new technology in procurement activities in developing countries has become a vital issue regarding management and information technological infrastructure. Brown and Thompson [14] reveal that technology infrastructure is one of three significant challenges identified in developing economies when applying e-government. Meanwhile, management support to provide a better quality of infrastructure in developing countries is less critical [15]. Thus, this study investigates the relationship between the implementation of e-procurement on company performance considering management support and information quality in Indonesia. This study uses a quantitative method by applying Partial Least Square-Structural Equation Modeling (PLS-SEM) based on variants or components. According to Hair et al. [16], PLS-SEM can confirm theory, explain the relationship between variables, and analyze constructs formed with formative and reflective indicators.

This article is written in five sections. Section 1 (introduction) discusses this study's background and identifies the gap between previous studies and the research statement. Section 4 discusses the related studies that contributed to developing the framework. The Section 3 discusses the research methodology, followed by Section 4 , which discusses the results and discussion. Section 5 presents the final section, which is the conclusion.

\section{Literature Review}

\subsection{The Role of E-Procurement}

E-procurement is a technology designed to simplify implementing goods and services through an electronic network or Electronic Data Interchange (EDI) [17]. The decree of the Republic of Indonesia's presidential regulation, number 54 of 2010, states that eprocurement, or electronic procurement, is the procurement of goods and services carried out using communication and information technology and electronic transactions under the law. E-procurement integrates communication and information systems (web-based) used in the procurement process, including resource search, negotiation, ordering, and purchasing [1]. Another definition stated by Gunasekaran et al. [18] state that e-procurement consists of the steps of an internet-based purchasing system. E-procurement refers to internet solutions that facilitate in-company purchases.

According to Davila et al. [19], electronic procurement (e-procurement) is the process of purchasing goods and services that is considered the most critical element in electronic business operational excellence for large companies. According to Oliveira and Amorim [20], the definition of e-procurement involves the procurement of goods and services, using the internet or electronic network in its implementation. Some of the objectives of e-procurement include increasing transparency accountability, improving market 
access and business competition, supporting the monitoring and auditing of processes, and meeting the needs for access to the latest information [21].

The implementation of e-procurement has been discussed from the perspective of procurement businesses. For example, Mali et al. [22] adopted blockchain technology in e-tendering to procure goods and materials. Blockchain in their study is implemented in tendering activities to implement a fair and transparent tendering scheme. In bidding processes, previous studies such as those of Rolas et al. [23] and San Santoso and Bourpanus [24] discussed the adoption of electronic media, including the internet, intranet, and electronic data interchange (EDI). Moreover, electronic information systems containing lists, types of technical specifications, and prices for certain goods and services from various providers can be provided using e-catalog [25]. This would be an effective way for parties to procure goods and materials according to their needs. Finally, in the transaction process, electronic purchasing indicates a positive and significant impact on procurement efficiency [26].

\subsection{Top Management Support}

Because of their position in the company, top management should direct its organizational activities. An organization will follow top management actions, directions, and efforts in determining the direction company development. Top management support's essential function is to make it the most essential and fundamental factor that affects a project's success. Top management support for e-procurement supports the procurement function in an electronic direction to be more efficient and transparent. On the other hand, top management are the decision-makers regarding the allocation of company resources. Management can also allocate adequate human resources to support actions in the organizational environment. Kumar et al. [27] argue that the importance of top management support comes from its ability to influence other human-resource-related factors. Senior management is the main allocator of resources, ensuring the successful implementation of e-procurement for a diverse allocation of resources, including human resources.

Distorted information communication can cause system failure. The World Bank suggests developing an e-procurement system in an open environment, allowing it to connect to other systems in order to simplify system upgrades. Management changes are needed to support the successful process of implementing e-procurement. Various opinions regarding change management appear to be more important as stakeholder needs increase. Increasing change in processes requires more learning and effort on the part of the user, according to [28]. As a result, more attention should be paid to changing management problems, and three ways are cited to achieve successful change management for e-procurement: consulting, communication, and problem-solving. In this regard, senior management should give sufficient attention to ensure that procurement changes are well understood [29]. The executive management team is responsible for setting the vision and objectives. They should also bring commitment collectively to changes in processes and organizational structure and formulate policies and strategies to implement e-procurement.

Previous studies indicated that senior management support is critical to creating a supportive climate and providing organizations with resources to implement IT innovation $[30,31]$. The implementation of information technology in procurement would require greater collaboration among the logistics partners of an organization in the supply chain to guarantee the achievement of the organization's main goals [32]. The challenge is how senior management manages and cultivates different goals with their logistics partner for implementing e-procurement. In several previous studies, the application of e-procurement appears to be more of a management problem than a problem of the information technology used $[5,31]$. This means that e-procurement cannot be implemented successfully without management support. Therefore, management support is an important factor for the implementation of e-procurement. Hence, the first hypothesis in this study is:

H1: Senior mop management support has a significant effect on the implementation of e-Procurement. 


\subsection{Information Quality}

In terms of the quality of information, it is clear that information technology platforms embedded in e-procurement play a significant role. Ronchi et al. [21] believe that e-procurement is gaining more popularity in business practices due to IT platform development. Another study by Alvarez-Rodríguez et al. [33] predicted that semantic technology would be the new trend in e-procurement applications. A semantic technology protocol, through a standard and shared data model, formal query language, and accessible via the internet, would tackle the challenges of delivering intelligent e-procurement. Quesada et al. [34] and Masudin and Kamara [35] suggested using electronic data interchange (EDI), file transfer protocol (FTP), video conference, and internet auctions to facilitate e-procurement. Meanwhile, in the development of information systems, blockchain technology is currently used for effective e-procurement. Akaba et al. [36] developed a framework for adopting blockchain-based e-procurement systems in public sector procurement. Moreover, Thio-ac [37] used blockchain to develop a secure, robust, and private system of e-procurement.

Previous discussions have shown that the quality of information plays a significant role in the successful implementation of e-procurement. Vaidyanathan and Devaraj [38] found that the quality of the information flow process, the logistics fulfillment process, and e-procurement satisfaction have a strong relationship. Kassim and Hussin [39] investigated the factors affecting the success of e-procurement for the Malaysian government. Their study shows that transparency, efficiency, and information quality are the most important factors contributing to the success of e-procurement. Another study by Ramantoko and Irawan [40] used the information system success model of DeLone and McClean (D\&M) to examine the factors influencing the information-sharing model in supporting the implementation of e-procurement services. Their study identified that service quality, system quality, and information quality significantly influence the perceived benefits of e-procurement adoption. Thus, in this study, we posit the second hypothesis:

H2: Quality information has a significant effect on the implementation of e-Procurement.

\subsection{E-Procurement Implementation and Company Performance Links}

Company performance is a complete display showing the company's state during a particular period, which is the result of achievement influenced by its operational activities in utilizing its resources. Company performance involves efficiency, sales performance, customer satisfaction, and relationship development. According to Chang and Wong [41], company performance, including efficiency, sales performance, customer satisfaction, and relationship development increases after participating in e-procurement. In previous studies by Suvanmanee et al. [42] and Williams et al. [43], customer satisfaction is the key to a company's success. The parties most directly related to customer satisfaction/dissatisfaction are marketers, customers, consumers, and customer behavior researchers. Competition between producers that offer products or services gives customers a chance to choose the best quality so that customers' bargaining power is higher. Consumer satisfaction is a behavioral response, in the form of an after-purchase evaluation of a product or service that they experience (product performance) compared to expectations or for a product or service. Gasperz [44] indicates that three factors influence consumer perceptions and expectations. First are the needs and desires related to consumers when trying to make a transaction with a product manufacturer/supplier (company). If these needs and desires are high, consumer expectations will be high and vice-versa. Secondly is the experience of consuming products from the company and its competitors. Thirdly, word of mouth will communicate a product's quality to other consumers. This affects consumer perceptions, especially with high-risk products.

According to Colletti et al. [45], company sales experience a life cycle in which sales will experience a decline at certain times, which may be due to a sales strategy no longer appropriate to market conditions. This situation encourages the company to implement new strategies in its sales management. Salespeople are needed who show high perfor- 
mance in achieving success $[46,47]$. Sales performance is also related to sales achievement. Croteau and Bergeron [48] and Saldanha et al. [49] believe that sales performance results from implementing various technological strategies, including e-procurement. Moreover, the implementation of e-procurement has gained more attention by organizations due to the potential saving as a key indicator of company performance. This is because some aspects of procurement such as sales and purchase activities, from searching, sourcing, negotiating, ordering, and receipt to post-purchase review, can be efficiently covered by e-procurement [50]. The use of internet-based technology for the application of eprocurement along with massive internet growth worldwide could connect more people and organizations. More stakeholder connections could deliver cost reductions, reorganization processes, contract fulfillment, and increased spending under management [51] Therefore, this study tests the hypothesis:

H3: The implementation of e-procurement has a significant effect on company performance.

\section{Research Methodology}

Indicators and variables were obtained from previous research. After obtaining these indicators and variables, a conceptual model and hypothesis were made. The next step was to make a questionnaire. There are two steps in distributing questionnaires. Firstly, closed questionnaires are distributed to respondents as a pilot test. The aim is to determine the questions' validity and reliability. The number of respondents to this closed questionnaire was 30. After obtaining data from the first questionnaire distribution, data processing will be conducted. The purpose is to determine the validity and reliability of the questions. Once considered valid and reliable, it will be followed by the final questionnaire distribution, which will be analyzed using PLS-SEM. This e-procurement adoption study's research object are medium and big manufacturers located in East Java province, Indonesia which have more than 100 employees [52]. The survey took place in major manufacturing industries such as chemicals, textiles, and electronic products. The selection of these types of industry was based on the fact that manufacturing industry provides the largest value of the gross domestic product in East Java province $(29.48 \%)$ compared to other types of industry [53]. Organization managers and decision-makers are selected by purposive random sampling with a sample size of 10 times the number of latent variables [54], i.e., 60 samples. The response rate was $75 \%$ of the selected procurement managers. Five point-scale measurements (strongly disagree $=1$ to strongly agree $=5$ ) are used to measure the respondent's answer. Respondents are asked to choose from these scales appropriate statements containing e-procurement implementation and company performance.

After distributing the final questionnaire and obtaining the data, the validity and reliability test will then be carried out on the final questionnaire. PLS-SEM will describe the path diagram to evaluate the measurement model (outer model). This includes the convergent validity test, discriminant validity test (cross-loading), validity test for AVE value, composite reliability test, and evaluation of the structural model (inner model), including the R-square test, path coefficient test, and hypothesis testing.

The conceptual model explains the relationship between the related variables, which will form its hypothesis. The conceptual model in this study is as follows.

Figure 1 is a conceptual model that illustrates the relationship of senior management support, information quality, and implementation of e-procurement with company performance. Based on the conceptual model above, the following hypotheses are formulated as in Table 1. 


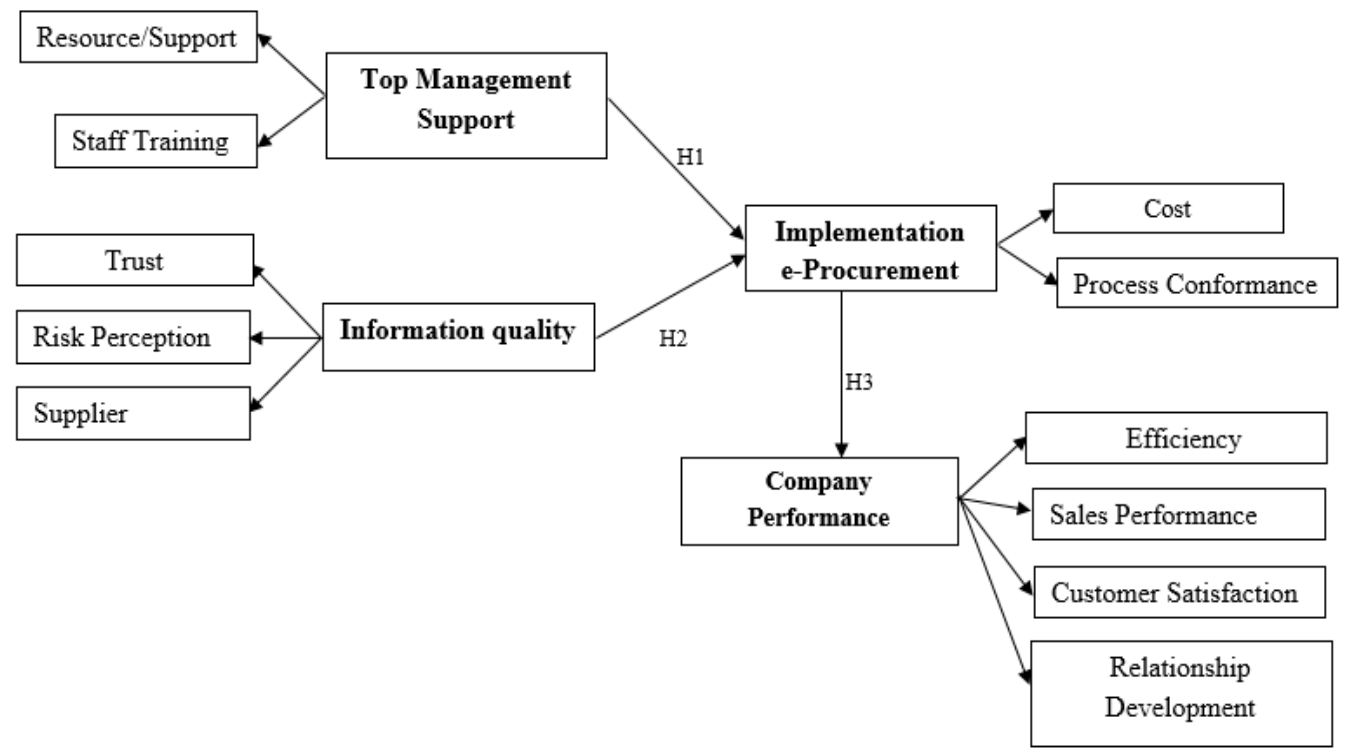

Figure 1. Conceptual model.

Table 1. Hypotheses regarding the relationship of e-procurement implementation to company performance.

\begin{tabular}{ll}
\hline & \multicolumn{1}{c}{ Hypothesis } \\
\hline H1 & $\begin{array}{l}\text { Top management support has a significant effect on the implementation of } \\
\text { e-procurement }\end{array}$ \\
\hline H2 & Quality information has a significant effect on the implementation of e-procurement \\
\hline H3 & The implementation of e-procurement has a significant effect on company performance \\
\hline
\end{tabular}

\section{Results and Discussions}

\subsection{Descriptive Statistics}

The results were obtained from online-distributed formal questionnaires via a Google form. For formal questionnaire distribution, there were 80 respondents available (see Table 2). Respondents were chosen based on particular criteria, i.e., they are the staff of companies implementing e-procurement. Sixty returned samples were used for analysis. The profiles of respondents are summarized as follows.

Table 2. Profile of respondents.

\begin{tabular}{ccc}
\hline Profile & Number of Respondents & Percentage (\%) \\
\hline Gender & & \\
\hline Male & 42 & $66 \%$ \\
\hline Female & 18 & $34 \%$ \\
\hline Age & & \\
\hline $23-30$ years old & 32 & $60 \%$ \\
\hline $31-40$ years old & 16 & $24 \%$ \\
\hline $41-50$ years old & 7 & $9 \%$ \\
\hline$>50$ years old & 5 & $7 \%$ \\
\hline Length of time at work & & \\
\hline
\end{tabular}


Table 2. Cont.

\begin{tabular}{ccc}
\hline Profile & Number of Respondents & Percentage (\%) \\
\hline $1-5$ years & 21 & $37 \%$ \\
\hline $6-10$ years & 17 & $24 \%$ \\
\hline$>10$ years & 22 & $39 \%$ \\
\hline
\end{tabular}

The descriptive statistics show that each indicator can be seen from the mean, standard deviation, minimum value, and maximum value as follows: Table 3 shows the respondents tendency towards the average assessment of variables and indicators. The highest average value obtained by the senior management support variable was 4.65 , with a standard deviation value of 0.50 .

Table 3. Descriptive statistics.

\begin{tabular}{|c|c|c|c|c|c|c|c|}
\hline Variable & Indicator & $n$ & Mean Value & Mean & $\begin{array}{l}\text { Standard } \\
\text { Deviation }\end{array}$ & Min & Max \\
\hline \multirow{2}{*}{ Top Management Support } & Resource/support (RS) & 60 & 4.68 & \multirow{2}{*}{4.65} & 0.50 & 3 & 5 \\
\hline & Staff training (ST) & 60 & 4.62 & & 0.51 & 3 & 5 \\
\hline \multirow{3}{*}{ Information Quality } & Trust & 60 & 4.10 & \multirow{3}{*}{4.24} & 0.87 & 2 & 5 \\
\hline & Risk perception (RP) & 60 & 4.35 & & 0.70 & 2 & 5 \\
\hline & Supplier (SUPP) & 60 & 4.27 & & 0.79 & 2 & 5 \\
\hline \multirow{2}{*}{$\begin{array}{l}\text { Implementation of } \\
\text { e-Procurement }\end{array}$} & Cost & 60 & 4.41 & \multirow{2}{*}{4.22} & 0.69 & 3 & 5 \\
\hline & Process conformance (PC) & 60 & 4.03 & & 0.75 & 2 & 5 \\
\hline \multirow{4}{*}{ Company Performance } & Efficiency (EFF) & 60 & 4.37 & \multirow{4}{*}{4.08} & 0.60 & 3 & 5 \\
\hline & Sales performance (SP) & 60 & 3.85 & & 0.89 & 2 & 5 \\
\hline & Customer satisfaction (CS) & 60 & 3.98 & & 0.92 & 2 & 5 \\
\hline & Relationship development (RD) & 60 & 4.13 & & 0.718 & 3 & 5 \\
\hline
\end{tabular}

\subsection{PLS-SEM (Partial Least Square-Structural Equation Modeling) Analysis}

This research study uses the PLS-SEM (Partial Least Square-Structural Equation Modeling) analysis tool. This study will explain the implementation of e-procurement effect on company performance, which will later be illustrated with a path diagram. In the path diagram, all to-be-studied variables and indicators will be linked.

An evaluation will be carried out for the measurement model (outer model) after depicting the path diagram. This includes the convergent validity test, discriminant validity test (cross-loading), validity test for AVE (Average Variance Extracted) value, composite reliability test, and evaluation of the structural model (inner model), including the R-square test, path coefficient test, and hypothesis testing.

\subsection{Path Diagram}

In this study, hypothesis testing used the Partial Least Square (PLS) analysis technique with the SmartPLS v3.0 program OSmartPLS GmbH. Variables and indicators in the path diagram are distinguished, in which the variables are blue and circular, and the indicators are yellow and rectangular. Variables and indicators are measured using a questionnaire instrument and imported into Excel (.cvs file) before being processed in SmartPls v3.0. Figure 2 is the path diagram for the PLS program being tested: 


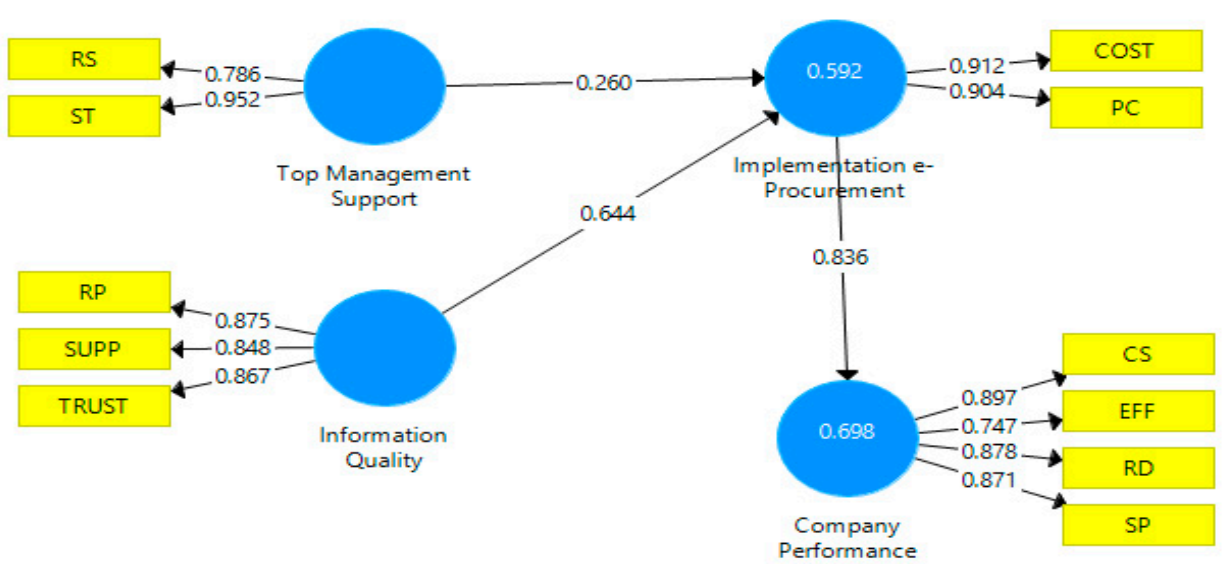

Figure 2. Path diagram.

\subsection{Evaluation of Measurement Model (Outer Model)}

The evaluation of the measurement model (Outer Model) includes the convergent validity test, discriminant validity test, and composite reliability test.

\subsection{Convergent Validity Test and Discriminant Validity}

For convergent validity, the outer loading or loading factor value is used. An indicator is declared to meet the 'good' category for convergent validity if the outer loading value is $>0.7$. In addition to observing the cross-loading value, discriminant validity can also be determined through other methods, namely by looking at the average variant extracted (AVE) value for each indicator. This requires a value of $>0.5$ for a 'good' model.

Table 4 shows that each indicator variable has a loading factor value $>0.7$, so this study's indicators can be said to be valid. The validity of the ST indicator has the highest validity value, namely 0.952 . This means that staff training indicators can explain the results of this study.

Table 4. Validity test.

\begin{tabular}{cccc}
\hline Variables & Indicators & Loading Factor & Evidence \\
\hline \multirow{2}{*}{ Top management support } & RS & 0.786 & Valid \\
\cline { 2 - 4 } & ST & 0.952 & Valid \\
\cline { 2 - 4 } Information quality & TRUST & 0.867 & Valid \\
\cline { 2 - 4 } & RP & 0.875 & Valid \\
\cline { 2 - 4 } Implementation of e-procurement & SUPP & 0.848 & Valid \\
\cline { 2 - 4 } & COST & 0.912 & Valid \\
\hline \multirow{2}{*}{ Company performance } & PC & 0.904 & Valid \\
\cline { 2 - 4 } & EFF & 0.747 & Valid \\
\cline { 2 - 4 } & SP & 0.871 & Valid \\
\cline { 2 - 4 } & CS & 0.897 & Valid \\
\hline
\end{tabular}

\subsection{Discriminant Validity Test (Cross Loading)}

Table 5 shows that each indicator in the research variable has a higher cross-loading value on the variable it forms than the cross-loading value on other variables. It can be seen that the RS and ST indicators have a higher correlation to the associated construct, namely, the top management support variable, with correlation coefficients of 0.786 and 0.952. Based on the results obtained, it can be stated that the indicators used in this study have good discriminant validity in compiling their respective variables. 
Table 5. Results of cross loading value.

\begin{tabular}{ccccc}
\hline Indicator & $\begin{array}{c}\text { Top Management } \\
\text { Support }\end{array}$ & $\begin{array}{c}\text { Information } \\
\text { Quality }\end{array}$ & $\begin{array}{c}\text { Implementation of } \\
\text { E-Procurement }\end{array}$ & $\begin{array}{c}\text { Company } \\
\text { Performance }\end{array}$ \\
\hline RS & 0.786 & 0.239 & 0.251 & 0.245 \\
\hline ST & 0.952 & 0.321 & 0.508 & 0.383 \\
\hline TRUST & 0.243 & 0.867 & 0.676 & 0.787 \\
\hline RP & 0.253 & 0.875 & 0.582 & 0.584 \\
\hline SUPP & 0.354 & 0.848 & 0.622 & 0.603 \\
\hline COST & 0.560 & 0.613 & 0.912 & 0.783 \\
\hline PC & 0.290 & 0.712 & 0.904 & 0.733 \\
\hline EFF & 0.356 & 0.488 & 0.638 & 0.747 \\
\hline SP & 0.260 & 0.672 & 0.713 & 0.871 \\
\hline CS & 0.339 & 0.827 & 0.795 & 0.897 \\
\hline RD & 0.329 & 0.592 & 0.684 & 0.878 \\
\hline
\end{tabular}

In addition to observing the cross-loading value, discriminant validity can also be determined through other methods, namely by looking at the average variant extracted (AVE) value for each indicator. This requires a value of $>0.5$ for a 'good' model.

In Table 6, it can be seen that each variable has an AVE value greater than 0.5. Thus, it can be stated that each variable has good discriminant validity.

Table 6. Results of Average Variance Extracted (AVE) value.

\begin{tabular}{cll}
\hline Variable & AVE & Evidence \\
\hline Top management support & 0.762 & Reliable \\
\hline Information quality & 0.746 & Reliable \\
\hline Implementation of e-procurement & 0.824 & Reliable \\
\hline Company performance & 0.723 & Reliable \\
\hline
\end{tabular}

\subsection{Reliability Test}

Composite reliability is the part used to test the reliability value of indicators on a variable. A variable can be declared to meet composite reliability if it has a composite reliability value $>0.7$.

Table 7 shows that the composite reliability value of each variable is more significant than 0.7 . The information quality variable has the highest composite reliability. Therefore it can be concluded that all variables have good composite reliability.

Table 7. Results of composite reliability value.

\begin{tabular}{ccl}
\hline Variable & Composite Reliability & Evidence \\
\hline Top management support & 0.864 & Reliable \\
\hline Information quality & 0.898 & Reliable \\
\hline Implementation of e-procurement & 0.903 & Reliable \\
\hline Company performance & 0.912 & Reliable \\
\hline
\end{tabular}

\subsection{Structural Model Evaluation (Inner Model)}

Evaluation of the structural model (inner model) aims to determine the relationship between construct variables and is also used to determine the contribution of exogenous variables to endogenous variables. In this study, the structural model's evaluation (inner 
model) includes an analysis of the coefficient of determination (R-square), path coefficient, and hypothesis testing.

\subsection{Coefficient of Determination (R-Square)}

The coefficient of determination or $\mathrm{R}^{2}$ is used to evaluate the structural model. The Rsquared $\left(R^{2}\right)$ value is used to measure how great the influence of a particular independent latent variable has on the latent dependent variable.

In Table 8, it can be seen that the R-Square value for the implementation of the eprocurement variable is 0.592 . The acquisition of this value shows that the internal audit of $59.2 \%$ can explain the percentage of the implementation of e-procurement. Meanwhile, the R-Square value obtained by the company performance variable is 0.698 . This value shows that the internal audit of $69.8 \%$ can explain company performance.

Table 8. Results of R-square value.

\begin{tabular}{cc}
\hline Variable & R-Square \\
\hline Implementation of e-procurement & 0.592 \\
\hline Company performance & 0.698 \\
\hline
\end{tabular}

\subsection{Path Coefficient}

Path coefficient evaluation show how strong is the effect or influence of the independent variable on the dependent one. The path coefficient value is obtained through the bootstrapping procedure, whose value ranges from -0.1 to +0.1 . The following is the result of the coefficient path value.

Table 9 explains that the highest path coefficient value is shown by the effect of Implementation of e-procurement on company performance, with a value of 0.836 . The second most significant influence is information quality on the implementation of e-procurement, with a value of 0.644 . Meanwhile, the smallest is shown by senior management support on the implementation of e-procurement, with a value of 0.60 . The description of these results shows that all variables in this model have a favorable path coefficient, and that the greater the path coefficient values of one independent variable on the dependent variable, the stronger the influence between the independent variables and the dependent variable.

Table 9. Results of path coefficient value.

\begin{tabular}{cc}
\hline Variable & Original Sample \\
\hline Top management support-> Implementation of e-procurement & 0.260 \\
\hline Information quality-> Implementation of e-procurement & 0.644 \\
\hline Implementation of e-procurement-> Company performance & 0.836 \\
\hline
\end{tabular}

\subsection{Hypothesis Testing}

Based on the data processing, the results can be used to answer the hypotheses in this study. The function of the $t$-test is to test how influential the independent variable (exogenous variable) is on the dependent variable (endogenous variable). The test criteria state that the $t$-Statistic value is $\geq t$-Table. This study used a confidence level of $95 \%$ ( $\alpha$ of $5 \%$ ) so that $t$-Table $=1.96$. The results of hypothesis testing can be seen in Table 10 . 
Table 10. Results of hypothesis testing.

\begin{tabular}{cccc}
\hline Hypotheses & \multicolumn{1}{c}{ Relationship Description } & $\boldsymbol{t}$-Statistic & Evidence \\
\hline $\mathrm{H} 1$ & $\begin{array}{c}\text { Management support has a significant effect } \\
\text { on the implementation of e-procurement }\end{array}$ & 3.025 & Significant \\
\hline $\mathrm{H} 2$ & $\begin{array}{c}\text { Information quality has a significant effect } \\
\text { on the implementation of e-procurement }\end{array}$ & 9.887 & Significant \\
\hline $\mathrm{H} 3$ & $\begin{array}{l}\text { The implementation of e-procurement has a } \\
\text { significant effect on company performance }\end{array}$ & 23.315 & Significant \\
\hline
\end{tabular}

H1: Senior management support has a significant effect on the implementation of e-procurement.

In this study, senior management support has a significant effect on the implementation of e-procurement. This effect was previously tested in data processing, while the $\mathrm{t}$-statistical value for $\mathrm{H} 1$ values reached a significant level. It is also supported by Vaidya et al. [28], who explain that the importance of senior management support comes from its ability to influence other human-resource-related factors thoroughly. Senior management is the main allocator of resources and can ensure the successful implementation of e-procurement with a diverse allocation of resources, including human resources.

Senior management support within the company must be aware that the primary function of e-procurement is to facilitate a more effective and efficient procurement process [2]. Ibem at al. [55] explain the three most important factors affecting an organization's decision to use e-procurement. They are the type of organization, senior management support, and the organization's attitude towards global trends in e-procurement.

From the results obtained from the path coefficient test in the inner model evaluation, it can be explained that the influence of senior management support on the implementation of e-procurement has the second most significant level among the other three variables. These results support research conducted by Fu et al. [56] that senior management support led to the mapping of the implementation plan and a complete series of actions. The company also makes good use of external resources to promote the project.

H2: Information quality has a significant effect on the implementation of e-procurement.

In this study, Information Quality has a significant effect on the implementation of e-procurement. This effect was previously tested in data processing, while the t-statistical value for $\mathrm{H} 2$ values reached a significant level. It is also supported by Mose et al. [57], who state that information quality is used to describe e-commerce (web) problems. In the context of successful electronic procurement, web-based applications must be personalized, complete, relevant, and easy to understand, and ensure the expected buyers or suppliers make transactions via the internet. According to Davis et al. [58], there are three constructs in the service quality dimension: trust, perceived risk, and ease of use. Trust in e-commerce is considered necessary because of the high degree of uncertainty and risk in most online transactions. It is also necessary for companies to ensure that all perceived risks are properly-handled. The implementation of e-procurement is closely related to supplier involvement. In implementing e-procurement, it is important to maintain mutual trust between sellers and buyers (suppliers) because all transactions are carried out online (internet). According to Ramantoko and Irawan [40], information quality has a significant effect on perceptions in supporting the implementation of e-procurement through usability and user satisfaction. Kassim \& Hussin [39] predict the success of a public e-procurement system. This study finds that electronic behavior contributes to improving service performance, efficiency, transparency, and information quality. The hypothesis testing results show that the $t$-statistics value of 9.085 is significant ( $\alpha$ is $5 \%$ ) so that the $t$-table $=1.96$, which means that the $t$-statistics value is greater than the $t$-table. This shows that there is a positive influence between information quality and the implementation of e-procurement.

H3: Implementation of e-procurement has a significant effect on company performance. 
In this study, the implementation of e-procurement has a significant effect on company performance. This effect was previously tested in data processing, while the t-statistical value for $\mathrm{H} 3$ values reached a significant level. It is also supported by Chang and Wong [41], who state that e-procurement implementation increases competitive advantage by increasing the efficiency of procurement activities and serving customers efficiently.

This strengthens research by Sumah, Masudin, Zulfikarijah, and Restuputri [59], who state that optimal company performance is the primary goal. Therefore, any changes in processes or technology must have a positive impact on company performance. E-procurement is involved in improving the procurement process and affects company performance both from a financial and non-financial perspective. According to Raghavan and Prabhu [60], e-procurement has several advantages: reducing overall procurement costs compared to current traditional methods, enabling shorter processing and order fulfillment cycles, reducing administrative costs, increasing strategic resources, and reducing inventory costs.

From the results of the path coefficient test in the inner model evaluation, it can be seen that the effect of e-procurement implementation on company performance has the highest significant level among the other three variables. Oh and Yang support this result, and Kim [61] shows that additional factors such as IT capabilities can help companies improve their performance through the implementation of e-procurement.

\subsection{Theoretical Contribution}

This section discusses theoretical contributions from the results of this study. This study's findings could enrich discussion of the usage of e-procurement for manufacturing sectors, from a developing country perspective. Most studies have previously discussed the implementation of e-procurement in developed countries with advanced infrastructures and educated human resources. This study's findings indicate that management support has a lower impact on the implementation of e-procurement than information technology quality. This result is not in line with the study results of Teo et al. [2]. Their study found that organizational factors are more important in e-procurement implementation in Singapore than technological factors. Dooley et al. [5] also indicate that internal organization factors play a more significant role than technological factors in developed nations (Australia). This concludes that the information technology infrastructure is still more significant than organizational factors when implementing e-procurement in developing economies.

This study also indicates that the adoption of e-procurement in Indonesian manufacturing industries impacts the organization's performance. Technological factors impact the implementation of e-procurement. The indicators of trust and risk perception are the factors that significantly affect the technological factors variable in e-procurement implementation. This indicates that the employee perceives new technology information applied in e-procurement in Indonesian manufacturing industries as positive and significant. This study's results are relevant to a study by Masudin et al. [62], who found that the perceived readiness of technology adoption among Indonesian employees in the manufacturing sector is not significant as it is in the retail sector. Moreover, Sani [62] showed that the availability of a quality information system in logistical operations would help employees trust that technology implementation could be implemented appropriately. This also relates to potentially harmful consequences.

\subsection{Managerial Implications}

This section consists of the analysis results and managerial implications for the implementation of e-procurement on company performance. Managerial implications aim to develop organizational policies that are expected to provide theoretical contributions to management practice. The resulting analysis of the loading factor value aims to determine the indicators that influence company performance in implementing e-procurement. The company's first recommendation regarding information quality that affects company performance is conducting staff training or job training for e-procurement staff. Dooley and Purchase [5] believe that one of the factors influencing e-procurement usage is staff 
skills. Moreover, staff training is crucial for implementing e-procurement [28]. Thus, internal organizational supports should allocate a budget for sufficient staff training in using e-procurement platforms. For a company that uses new technology or platforms for its e-procurement, it is highly recommended that the management provide adequate staff training [57].

The second recommendation for companies regarding the quality of the information provided by e-procurement implementation is selecting appropriate technology or platforms. E-procurement technology or platforms play a significant role in the implementation of e-procurement [21]. Senior internal management of the organization should provide a platform or appropriate technology for e-procurement and its infrastructures. The selection of platforms for the usage of e-procurement should consider the risk [63], the future trend [33], the effectiveness, and the costs [20]. The selection of e-procurement platforms should also consider the type of organizations and users who use them. Some approaches can measure the acceptance of e-procurement platforms. Staff and customers' readiness for using e-procurement technology can be measured by the technology readiness index $[64,65]$. In contrast, the acceptance of e-procurement technology for users or customers can be rated by the technology acceptance model [66].

\section{Conclusions}

An investigation of the influence of the adoption of e-procurement on organizational performance was conducted. This study shows that senior management involvement and information quality are the variables that may affect the adoption of e-procurement. The results indicated that all variables involved in the framework, such as senior management and information quality, significantly affect the implementation of e-procurement. Moreover, the implementation of e-procurement on the company has a significant effect on organization performance. The findings of this study could be considered by policymakers in making managerial policies. Some managerial policies such as the involvement of management in strengthening the adoption of electronic technology adoption in procurement and increasing staff's ability to adopt this technology could be implemented. For future research, the adoption of electronic technology, such as the internet of things, EDI, RFID, and blockchain, could be discussed in other business processes for better organization performance.

Author Contributions: Conceptualization, I.M., A.N., and D.P.R.; methodology, G.D.A.; software and model validation, I.M. and G.D.A.; investigation and analysis, G.D.A. and A.N.; writing-review and editing, I.M. and D.P.R.; supervision, I.M. All authors have read and agreed to the published version of the manuscripts.

Funding: The research received no external funding.

Institutional Review Board Statement: Not applicable.

Informed Consent Statement: Not applicable.

Data Availability Statement: Study did not report any data.

Conflicts of Interest: The authors declare no conflict of interest.

\section{References}

1. Croom, S.; Brandon-Jones, A. Impact of e-procurement: Experiences from implementation in the UK public sector. J. Purch. Supply Manag. 2007, 13, 294-303. [CrossRef]

2. Teo, T.S.; Lin, S.; Lai, K.-h. Adopters and non-adopters of e-procurement in Singapore: An empirical study. Omega 2009, 37, 972-987. [CrossRef]

3. Gunasekaran, A.; Ngai, E.W.T. Adoption of e-procurement in Hong Kong: An empirical research. Int. J. Prod. Econ. 2008, 113, 159-175. [CrossRef]

4. Croom, S.R.; Brandon-Jones, A. Key issues in e-procurement: Procurement implementation and operation in the public sector. J. Public Procure 2005, 5, 367-387. [CrossRef]

5. Dooley, K.; Purchase, S. Factors influencing e-procurement usage. J. Public Procure 2006, 6, 28-45. [CrossRef] 
6. Roehrich, J.K.; Davies, A.; Frederiksen, L.; Sergeeeva, N. Management innovation in complex products and systems: The case of integrated project teams. Ind. Mark. Manag. 2019, 79, 84-93. [CrossRef]

7. King, J.L.; Gurbaxani, V.; Kraemer, K.L.; McFarlan, F.W.; Raman, K.; Yap, C.-S. Institutional factors in information technology innovation. Inf. Syst. Res. 1994, 5, 139-169. [CrossRef]

8. Laryea, S.; Ibem, E.O. Patterns of Technological Innovation in the use of e-Procurement in Construction. J. Inf. Technol. Constr. 2014, 19, 104-125.

9. Tai, Y.-M.; Ho, C.-F.; Wu, W.-H. The performance impact of implementing web-based e-procurement systems. Int. J. Prod. Res. 2010, 48, 5397-5414. [CrossRef]

10. Priya, P.; Iyakutti, K.; Devi, S.P. E-procurement system with embedded supplier selection DSS for an automobile manufacturing industry. Int. J. Database Manag. Syst. 2012, 4, 85. [CrossRef]

11. Benyoucef, M.; Canbolat, M. Fuzzy AHP-based supplier selection in e-procurement. Int. J. Serv. Oper. Manag. 2007, 3, 172-192. [CrossRef]

12. Singh, R.K.; Benyoucef, L. A fuzzy TOPSIS based approach for e-sourcing. Eng. Appl. Artif. Intell. 2011, 24, 437-448. [CrossRef]

13. Tyagi, M.; Kumar, P.; Kumar, D. A hybrid approach using AHP-TOPSIS for analyzing e-SCM performance. Procedia Eng. 2014, 97, 2195-2203. [CrossRef]

14. Brown, D.H.; Thompson, S. Priorities, policies and practice of e-government in a developing country context: ICT infrastructure and diffusion in Jamaica. Eur. J. Inf. Syst. 2011, 20, 329-342. [CrossRef]

15. Tutu, S.O.; Kissi, E.; Osei-Tutu, E.; Desmond, A. Evaluating critical factors for the implementation of e-procurement in Ghana. Int. J. Procure Manag. 2019, 12,1-14. [CrossRef]

16. Hair, J.F.; Risher, J.J.; Sarstedt, M.; Ringle, C.M. When to use and how to report the results of PLS-SEM. Eur. Bus. Rev. 2019, 31, 2-24. [CrossRef]

17. Aboelmaged, M.G. Predicting e-procurement adoption in a developing country. Ind. Manag. Data Syst. 2010, 110, 392-414. [CrossRef]

18. Gunasekaran, A.; McGaughey, R.E.; Ngai, E.W.; Rai, B.K. E-Procurement adoption in the Southcoast SMEs. Int. J. Prod. Econ. 2009, 122, 161-175. [CrossRef]

19. Davila, A.; Gupta, M.; Palmer, R. Moving procurement systems to the internet:: The adoption and use of e-procurement technology models. Eur. Manag. J. 2003, 21, 11-23. [CrossRef]

20. Oliveira, L.M.; Amorim, P.P. Public e-procurement. Int. Financ. Law Rev. 2001, 20, $43-47$.

21. Ronchi, S.; Brun, A.; Golini, R.; Fan, X. What is the value of an IT e-procurement system? J. Purch. Supply Manag. 2010, 16, 131-140. [CrossRef]

22. Mali, D.; Mogaveera, D.; Kitawat, P.; Jawwad, M. Blockchain-Based e-Tendering System. In Proceedings of the 20204 th International Conference on Intelligent Computing and Control Systems (ICICCS), Madurai, India, 13 May 2020 ; pp. $357-362$.

23. Rolas, S.; Foralisa Toyfur, M.; Juliantina, I. An Analysis of the Effect of Job Implementation Methods in the Failure of the Selection Procurement Process of Electronic Construction Service Providers (E-procurement) on the District of Musi Banyuasin. Int. J. Civ. Eng. Technol. 2019, 10, 313-322.

24. San Santoso, D.; Bourpanus, N. Moving to e-bidding. J. Financ. Manag. Prop. Constr. 2019, 24, 2-18. [CrossRef]

25. Anwar, T.A.; Saudi, M.H.M.; Sinaga, O. Build A ComPetitive Advantage Model for Non E-CataLog Products in Indonesia (A Study from Emergency Medical Kit). J. Adv. Manag. Sci. 2018, 6, 132-138. [CrossRef]

26. Vaidya, K.; Campbell, J. Multidisciplinary approach to defining public e-procurement and evaluating its impact on procurement efficiency. Inf. Syst. Front. 2016, 18, 333-348. [CrossRef]

27. Kumar, A.; Mangla, S.K.; Luthra, S.; Ishizaka, A. Evaluating the human resource related soft dimensions in green supply chain management implementation. Prod. Plan. Control 2019, 30, 699-715. [CrossRef]

28. Vaidya, K.; Sajeev, A.; Callender, G. Critical factors that influence e-procurement implementation success in the public sector. J. Public Procure 2006, 6, 70-99. [CrossRef]

29. Basheka, B.C.; Oluka, P.N.; Mugurusi, G. Adopting new approaches for public procurement efficiency: Critical success factors (CSFs) for the implementation of e-procurement in Uganda's public sector. Int. J. Procure Manag. 2012, 5, 712-732. [CrossRef]

30. DeLone, W.H. Determinants of success for computer usage in small business. Mis. Q. 1988, 12, 51-61. [CrossRef]

31. Li, Y.-H. An Empirical Investigation on the Determinants of e-Procurement Adoption in Chinese Manufacturing Enterprises. In Proceedings of the 2008 International Conference on Management Science and Engineering 15th Annual Conference Proceedings, Long Beach, LA, USA, 10 September 2008; pp. 32-37.

32. Zhu, Q.; Sarkis, J.; Cordeiro, J.J.; Lai, K.-H. Firm-level correlates of emergent green supply chain management practices in the Chinese context. Omega 2008, 36, 577-591. [CrossRef]

33. Alvarez-Rodríguez, J.M.; Labra-Gayo, J.E.; de Pablos, P.O. New trends on e-Procurement applying semantic technologies: Current status and future challenges. Comput. Ind. 2014, 65, 800-820. [CrossRef]

34. Quesada, G.; González, M.E.; Mueller, J.; Mueller, R. Impact of e-procurement on procurement practices and performance. Benchmarking Int. J. 2010, 17, 516-538. [CrossRef]

35. Mas'udin, I.; Kamara, M.S. Electronic Data Interchange and Demand Forecasting Implications on Supply Chain Management Collaboration: A Customer Service Perspective. J. Tek. Ind. 2017, 18, 138-148. [CrossRef] 
36. Akaba, T.I.; Norta, A.; Udokwu, C.; Draheim, D. A Framework for the Adoption of Blockchain-Based e-Procurement Systems in the Public Sector. In Proceedings of the Conference on e-Business, e-Services and e-Society, Skukuza, South Africa, 6-8 April 2020; pp. 3-14.

37. Thio-ac, A.; Domingo, E.J.; Reyes, R.M.; Arago, N.; Jorda, R., Jr.; Velasco, J. Development of a secure and private electronic procurement system based on blockchain implementation. arXiv 2019, arXiv:1911.05391. [CrossRef]

38. Vaidyanathan, G.; Devaraj, S. The role of quality in e-procurement performance: An empirical analysis. J. Oper. Manag. 2008, 26, 407-425. [CrossRef]

39. Kassim, E.S.; Hussin, H. A success model for the Malaysian Government e-procurement system: The buyer perspective. Int. J. Electron. Gov. Res. (IJEGR) 2013, 9, 1-18. [CrossRef]

40. Ramantoko, G.; Irawan, H. Information Sharing Model in Supporting Implementation of e-Procurement Service: Case of Bandung City. Int. J. Supply Chain. Manag. 2017, 6, 252-257.

41. Chang, H.H.; Wong, K.H. Adoption of e-procurement and participation of e-marketplace on firm performance: Trust as a moderator. Inf. Manag. 2010, 47, 262-270. [CrossRef]

42. Suvanmanee, W.; Kee, D.M.H.; Lee, Z.W.; Low, C.M.; Zakwan, M.A.; Gupta, A.; Pandey, R.; Alfahad, F.F.; Quttainah, M.A. The relationship between customer satisfaction and organizational success: A study of Panasonic. J. Community Dev. Asia 2020, 3 , 48-57. [CrossRef]

43. Williams, P.; Ashill, N.J.; Naumann, E.; Jackson, E. Relationship quality and satisfaction: Customer-perceived success factors for on-time projects. Int. J. Proj. Manag. 2015, 33, 1836-1850. [CrossRef]

44. Gaspersz, V. Total Quality Management; GRAMEDIA: Jakarta, Indonesia, 1997.

45. Colletti, J.A.; Chonko, L.B. Change management initiatives: Moving sales organizations from obsolescence to high performance. J. Pers. Sell. Sales Manag. 1997, 17, 1-30.

46. Calixto, N.; Ferreira, J. Salespeople Performance Evaluation with Predictive Analytics in B2B. Appl. Sci. 2020, 10, 4036. [CrossRef]

47. DeConinck, J.; DeConinck, M.B. The relationship between servant leadership, perceived organizational support, performance, and turnover among business to business salespeople. Arch. Bus. Res. 2017, 5, 38-53. [CrossRef]

48. Croteau, A.-M.; Bergeron, F. An information technology trilogy: Business strategy, technological deployment and organizational performance. J. Strateg. Inf. Syst. 2001, 10, 77-99. [CrossRef]

49. Saldanha, T.; Pomirleanu, N.; John Mariadoss, B.L.; Mithas, S. Information Technology, Learning, and Sales Performance. 2020. Available online: https://aisel.aisnet.org/icis2020/is_workplace_fow /is_workplace_fow/18/(accessed on 14 March 2021).

50. Mohd Nawi, M.N.; Roslan, S.; Salleh, N.A.; Zulhumadi, F.; Harun, A.N. The benefits and challenges of E-procurement implementation: A case study of Malaysian Company. Int. J. Econ. Financ. Issues 2016, 6, 329-332.

51. Tiago, M.T.B.; Couto, J.P.A.; Tiago, F.B.; Cabral Vieira, J.A. Internet marketing adoption: Factors affecting website sophistication. Int. J. Electron. Cust. Relatsh. Manag. 2007, 1, 287-306. [CrossRef]

52. Masudin, I.; Wastono, T.; Zulfikarijah, F. The effect of managerial intention and initiative on green supply chain management adoption in Indonesian manufacturing performance. Cogent Bus. Manag. 2018, 5, 1485212. [CrossRef]

53. Bappeda. Series of Analysis of East Java Province 2015 Development; Indonesian Regional Development Planning Agency: Surabaya, Indonesia, 2016.

54. Barclay, D.; Higgins, C.; Thompson, R. The Partial Least Squares (PLS) Approach to Casual Modeling: Personal Computer Adoption Ans Use as an Illustration. Technol. Stud. 1995, 2, 285-309.

55. Ibem, E.O.; Aduwo, E.B.; Ayo-Vaughan, E.A.; Uwakonye, U.O.; Owolabi, J.D. E-procurement use in the Nigerian building industry. Int. J. Electron. Commer. Stud. 2017, 8, 219-254.

56. Fu, H.-P.; Chang, T.-H.; Wu, W.-H. An implementation model of an e-Procurement system for auto parts: A case study. Prod. Plan. Control 2004, 15, 662-670. [CrossRef]

57. Mose, J.M.; Njihia, J.M.; Magutu, P.O. The critical success factors and challenges in e-procurement adoption among large scale manufacturing firms in Nairobi, Kenya. Eur. Sci. J. 2013, 19, 375-401.

58. Davis, F.D.; Bagozzi, R.P.; Warshaw, P.R. User acceptance of computer technology: A comparison of two theoretical models. Manag. Sci. 1989, 35, 982-1003. [CrossRef]

59. Sumah, B.; Masudin, I.; Zulfikarijah, F.; Restuputri, D.P. Logistics Management and Electronic Data Interchange Effects on Logistics Service Providers' Competitive Advantage. J. Bus. Econ. Anal. 2020, 3, 171-194.

60. Raghavan, N.S.; Prabhu, M. Object-oriented design of a distributed agent-based framework for e-Procurement. Prod. Plan. Control 2004, 15, 731-741. [CrossRef]

61. Oh, S.; Yang, H.; Kim, S.W. Managerial capabilities of information technology and firm performance: Role of e-procurement system type. Int. J. Prod. Res. 2014, 52, 4488-4506. [CrossRef]

62. Sani, A. Integration of the Technology Readiness and Adoption Models for Assessing IT Use among SMEs in Indonesia. In Proceeding of the International Conference on Recent Innovation, Jakarta, Indonesia, 27 September 2018; pp. 1-9.

63. Kauffman, R.J.; Mohtadi, H. Proprietary and open systems adoption in e-procurement: A risk-augmented transaction cost perspective. J. Manag. Inf. Syst. 2004, 21, 137-166. [CrossRef]

64. Masudin, I.; Jie, F.; Widayat, W. Impact of halal supplier service quality and staff readiness to adopt halal technology on halal logistics performance: A study of Indonesian halal meat supply chain. Int. J. Agil. Syst. Manag. 2020, 13, 315-338. [CrossRef] 
65. Padhi, S.S.; Mohapatra, P.K. Information technology readiness index for adoption of e-procurement. Electron. Gov. Int. J. 2011, 8 , 20-39. [CrossRef]

66. Ramkumar, M.; Schoenherr, T.; Wagner, S.M.; Jenamani, M. Q-TAM: A quality technology acceptance model for predicting organizational buyers' continuance intentions for e-procurement services. Int. J. Prod. Econ. 2019, 216, 333-348. [CrossRef] 